\title{
油圧－電動ハイブリッド駆動型双腕ロボット
}

\author{
高 橋 宏 昌*1一田伸 治*1 原直 行*1 寺 井 藤 雄*1 \\ 風 間 拓 朗 $* 2$ 菅 野 健一郎*3 大 賀 淳一郎*4
}

\section{Hydraulic-and-electric Double-arm Robot}

\author{
Hiromasa Takahashi*1, Shinji Ichida*1, Naoyuki Hara*1, Fujio Terai*1, \\ Takuro Kazama*2, Kenichiro Kanno*3 and Junichiro Ooga*4
}

\begin{abstract}
The cell production method, which facilitates high-product-mix and low-volume manufacturing, has been expanding into the mainstream, and demand has been growing for a robot similar in size to workers that can dexterously act as a multiskilled worker and handle heavy materials in a cell production line.

We have developed a hydraulic double-arm robot that is equipped with hydraulic actuators for the arms, allowing it to handle heavy materials, and the TV800 vertical articulated robot arm consisting of electric actuators produced by Toshiba Machine Co., Ltd. For the wrists, allowing it to also achieve dexterous handling operations through visual feedback and compliance control.

Also, we have developed a new fault detection system equipped with this robot. This system can detect faults of materials, not only by visual inspection, but also by weight inspection using the pressure of hydraulic cylinder.
\end{abstract}

Key Words: Robot, Hydraulic-and-electric, Double Arm, Cell Production

\section{1.は じめに}

\section{1 セル生産方式の自動化ニーズ}

単一製品を大量に製造するライン生産方式では，ベルトコン ベアによって流れてくる製品に，部品を取り付けていく，その 作業は限定された単純な動作で成り立っていたため，それを正 確にすばやく行うことができるシングルアーム産業用ロボット が，1980 年代以降，自動車産業を中心に導入されてきた。その 一方で, 電気・電子産業では, 多様化する消費者ニーズに対応 するため多品種少量生産が求められ，ライン生産方式に代わっ てセル生産方式が主流となった。

七ル生産方式は，作業者が一人で製品の組み立てを完成させ るため, 高い習熟度を要し，作業自体が重労働であることから， 人員の確保が難しくなると予想されている. さらに，新興国へ の工場進出が進んだものの，人件費高騰により，安価で大量な

原稿受付 2014 年 12 月 8 日

${ }^{* 1}$ 株式会社東芝 生産技術センター

$* 2$ 東芝機械株式会社

*3東芝 IT コントロールシステム株式会社

$* 4$ 株式会社東芝 研究開発センター

${ }^{* 1}$ TOSHIBA Co., Ltd. Corporate Manufacturing Engineering Center

*2 TOSHIBA MACHINE Co., Ltd.

${ }^{*}$ Toshiba IT \& Control Systems Corporation

${ }^{* 4}$ TOSHIBA Co., Ltd. Corporate Research \& Development Center

口本論文は提案性（システム設計・構築分野）で評価されました。
労働力によるローコストオペレーションモデルが困難になりつ つある。以上から，七ル生産に対応したロボットが求められて きた。

これに対し，ロボットメーカなどから 1）シングルアーム産 業用ロボットを複数台活用したセル生産システム（ロボットセ ル），2）アーム 2 本をボディに取り付けた双腕型産業用ロボッ トが提案されている $[1]$.

\section{2 セル生産方式の自動化への問題点}

作業者によるセル生産方式への適用条件は，市場・製品設計 · 製造工程の三つの観点から, Table 1 のようにまとめられる [2]. これらの条件を満足していると，七ル生産方式の導入効果が得 られやすくなる．今までに提案されているロボットセルや双腕 型産業用ロボットは，これら条件を満足した製造ラインに導入 されている場合が多い.

その一方，対象製品が市場条件を満たしていても，製品設計 や製造工程条件を満足できなければ，セル生産方式の導入効果 が小さくなる，つまり，対象製品が多品種少量生産であっても， セル生産方式が有効であるとは言えない，具体的には洗濯機・ 冷蔵庫などの白物家電製品や中小型モータ・ポンプなどのイン フラ製品などが挙げられる。これら製品は，市場条件は合致し ているものの，構成部品が重いため，製品設計条件を満足する ことができない。これらの製品の製造ラインをセル化し，さら にはロボットによる自動化が望まれているが，そのためには 1) 重量物が搬送できること，2）人に近い器用な動作ができるこ 
Table 1 The conditions for successful implementation of assembly cells

\begin{tabular}{|c|c|}
\hline & The conditions for successful implementation of assembly cells \\
\hline $\begin{array}{c}\text { Market } \\
\text { conditions }\end{array}$ & $\begin{array}{l}\text { (1) Frequent model changes are necessary } \\
\text { (2) There are drastic fluctuations in demand } \\
\text { (3) The company has been obliged to } \\
\text { adopt small-lot multi-kind production }\end{array}$ \\
\hline $\begin{array}{l}\text { Product design } \\
\text { Conditions }\end{array}$ & $\begin{array}{l}\text { (1) Low total assembly man-hours } \\
\text { where production volume is high } \\
\text { (2) Small number of assembly components } \\
\text { (3) Small products and components }\end{array}$ \\
\hline $\begin{array}{l}\text { Manufacturing } \\
\text { process } \\
\text { Conditions }\end{array}$ & $\begin{array}{l}\text { (1) few difficult operations requiring a high level of proficiency } \\
\text { (2) High possibility of securing multi-skilled workers } \\
\text { because of the low production volume } \\
\text { (3) few difficult operations performing different functions } \\
\text { (4) few operations requiring a new manufacturing technology } \\
\text { (5) The difficulty difference of operations is small } \\
\text { (5) Small cquipmcnt } \\
\text { (5) No need for expensive equipment } \\
\text { or high possibility of sharing equipment }\end{array}$ \\
\hline
\end{tabular}

と，3）設備レイアウトを大幅に変更しないように人と同等サイ ズであることが必要である。従来のロボットセルや双腕型産業 用ロボットは，電動アクチュエータが使用されているため，小 型のものは出力が小さく，重量物を搬送することが難しい。 ま た，パラレルリンク機構を用いた場合，高出力が得られるもの の, 可動範囲がシリアルリンク機構のロボットと比べて非常に 小さい.

そこで筆者らは, 大きな負荷の掛かる上腕部には油圧アクチュ エータを，細かな作業を担う前腕部には電動アクチュエータを 組み合わせたシリアルリンク機構でアームを構成し，コンパク トで重量物を搬送できるロボットを開発した [3] [4]. そしてさ らに，油圧アクチュエータ内圧をセンシングすることで重量検 知機能をこのロボットに追加した，ここでは，その概要と特長 について述べる。

\section{2. 油圧一電動ハイブリッド駆動型双腕ロボット}

\section{1 目的}

前述のような要求に応えるため，以下のコンセプトに基づき 開発を行った。

(1) 高可搬質量

一般に製造ラインでは作業者による可搬制限を $20[\mathrm{~kg}]$ と設 定していることが多い。これは, 文献 [5] の I 重量物取扱い作 業 2 人力による重量物の取扱い（2）にて,「満 18 歳以上の男 子労働者が人力のみにより取り扱う物の重量は, 体重の㧍おむ ね 40\%以下となるように努めること. 満 18 歳以上の女子労働 者では，さらに男性が取り扱うことのできる重量の $60 \%$ 位まで とすること.」と記載されていることによる.

また，同資料の別紙 I 重量物取扱い作業 2 人力による重量物 の取扱いにおいて，「なお，一般に女性の持上げ能力は，男性の 60\%位である. また, 女性労働基準規則では, 満 18 歳以上の女 性で, 断続作業 $30 \mathrm{~kg}$, 継続作業 $20 \mathrm{~kg}$ 以上の重量物を取扱うこ とが禁止されている.」と記載されている.

以上より，本ロボットはアクチュエータ出力を高め，可搬質 量を $20[\mathrm{~kg}]$ 以上とすることを目標とする.

(2) 器用な動作

人に近い器用な動作ができるよう双腕型とし, カメラ画像に よるワーク等の動作環境認識能力を高める.

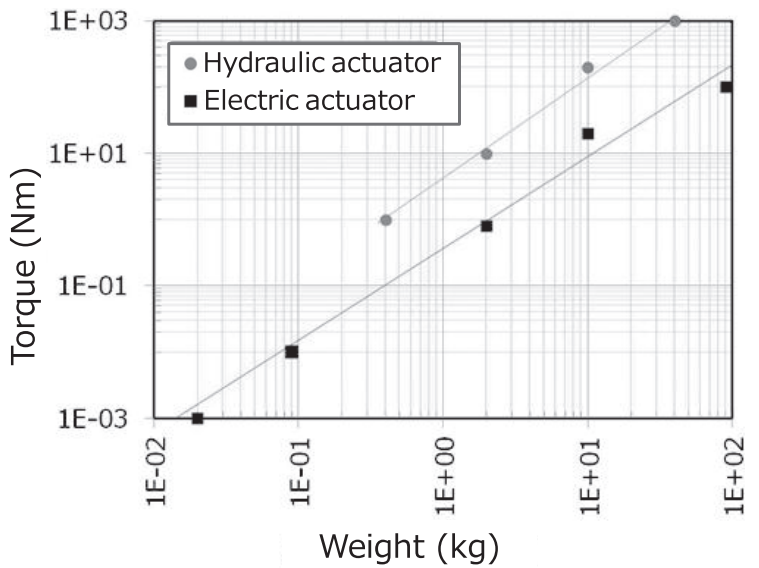

Fig. 1 Comparison of output torque of hydraulic and electric actuators（参考文献 [6] の記載デー夕に基づき作成）

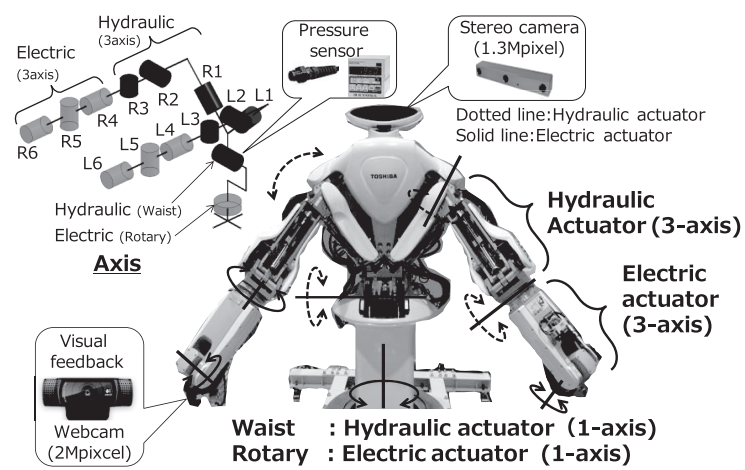

Fig. 2 Outline of hydraulic-and-electric double-arm robot

(3) コンパクト性

生産現場に適用しやすいよう, 人と同等サイズである肩幅 $700[\mathrm{~mm}]$ 程度とする.

\section{2 ハードウェア構成}

電動アクチュエータの出力トルクは，電機子の電流と磁束に 比例する，高出力を得るためには，コイルや磁石などの構成部 品を大きくしたり，ギヤを追加するなど部品点数を増やす必要 があるため, アクチュエータが大型化してしまう。

その一方, 油圧アクチュエータの出力は, 圧力と流量に比例 する. パスカルの原理を応用しているため, 圧力を上げるか，ピ ストンの面積比を高めることで高出力が得られる．Fig. 1 に， アクチュエータ質量とトルクの関係を示す。

Fig. 1 が示すように, 油圧アクチュエータは電動と比べて，同 一質量でも 5〜10 倍程度の出力を得ることができる.

そこで，今回は上腕部には油圧アクチュエータを，前腕部には 電動アクチュエータを組み合わせたシリアルリンク機構のアー ム構成とした. Fig. 2 に開発したロボットの外観図を示す。人 と同程度の可動域を目指し，油圧アクチュエータはシリンダタ イプを採用し，前腕部の電動アクチユエータはシングルアーム 産業用ロボット（東芝機械（株）製 TV800 [7]）の 3 軸を使用 した. TV800 は手先部の交換が可能な機構となっており，セル 生産で必要とされるねじ締め, 塗布, 検査などの複数の作業に 対応可能である. 


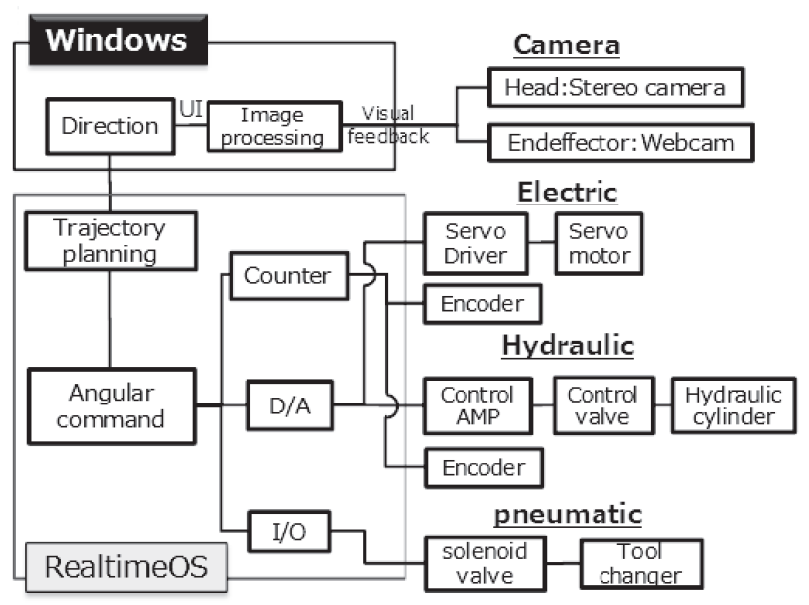

Fig. 3 Configuration of hydraulic-and-electric double-arm robot

その結果, あらゆる姿勢に対応可能な可搬質量は $5[\mathrm{~kg}]$ であ るが, 手首を重力方向に向けて用いるなど, 特定姿勢での可搬 質量は片腕で $50[\mathrm{~kg}]$ を実現することができた.

\section{3 ソフトウェア構成}

制御コントローラでは，事前に作成した組立指示情報に従い， リアルタイムに各軸の関節角度を生成し, 各駆動部に動作指令 を出す，ロボットのシステム構成図を Fig. 3 に示す.

油圧アクチュエータは, 油圧バルブの開度を連続的に変化さ せることで制御する。油圧バルブはコントローラから D/A を 介してコントローラアンプによって電圧を変化させて制御して いる．このバルブの開度を制御するために，ロボットの関節軸 に取り付けたロータリーエンコーダの角度速度の值から計算し た速度を流量の近似值として使用し，この流量相当値をフィー ドバックしている．油圧アクチュエータは小型で高出力といっ た長所がある一方で, 電動アクチュエータと比べて一般に位置 決め精度や応答性が劣る，上記のように，油圧流量を制御する 油圧バルブに, 流量変化に基づくフィードバック制御を適用す ることで, 制御性能を高めている. 詳細な制御方法や実験結果 は 3.2 節にて述べる.

また，ロボットの手首部に手先位置補正用の二次元カメラ を搭載している．このカメラを用いた視覚フィードバック制御 (Look\&move 動作) により, 対象物の置かれた位置に応じて, アームの手先位置決め補正を行うことができる，現在，ロボッ トの手先のコンプライアンス制御機能の開発も進めており, そ れが完成すると, 生産現場で必要とされるピン挿入作業もでき るようになる.ささらに, ヘッド部にはワークやジグなどの動作 環境を認識するためにステレオカメラを搭載しており, ワーク 周辺の三次元（3D）情報を検出することが可能である.

以上より，本ロボットの仕様を Table 2 にまとめる.

油圧アクチュエータと電動アクチュエータのシリアルリンク 機構の構成により, 人と同等サイズの肩幅 $700[\mathrm{~mm}]$ で, 片腕 での可搬質量 $50[\mathrm{~kg}]$ を実現した。これは Fig. 4 に示すとおり， 一般的な双腕型産業用ロボットと比べても, コンパクトで可搬質 量が大きく，現在のセル生産現場により対応しやすいといえる.
Table 2 Specification of hydraulic-and-electric double-arm robot

\begin{tabular}{l|c}
\hline Size & Specification \\
\hline Load & $\begin{array}{c}\text { Shoulder : 700mm } \\
\text { Upper arm : 460mm } \\
\text { Lower arm : } 580 \mathrm{~mm}\end{array}$ \\
\hline D.O.F & Max 50kg (100kg by double arm) \\
\hline Actuators & 7axis : Hydraulic 7axis : electric \\
\hline Controller & $\begin{array}{c}\text { Compliance control } \\
\text { Visual control } \\
\text { flow feedback control }\end{array}$ \\
\hline Sensors & $\begin{array}{c}\text { Head : Stereo camera (Detection of parts) } \\
\text { Endeffector : Webcam (Detect of position ) }\end{array}$ \\
\hline
\end{tabular}

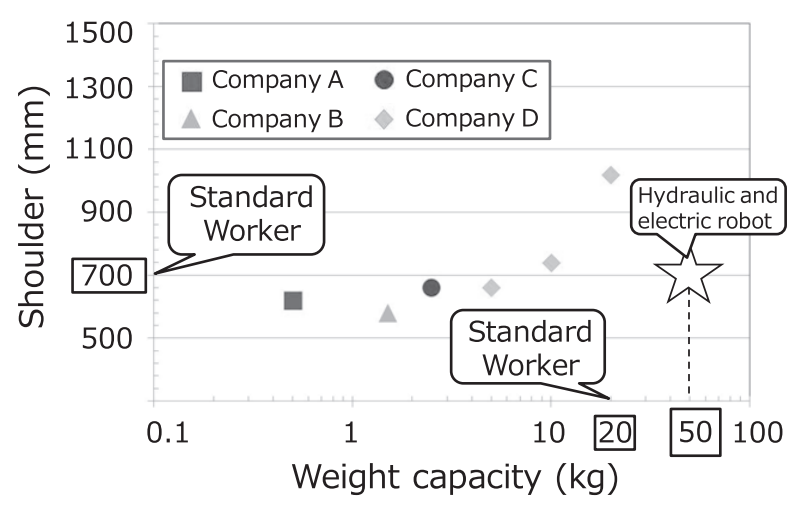

Fig. 4 Benchmark comparison of various double-arm robots

\section{3. 技術課題とその取り組み}

\section{1 ロボット動作シミュレータ}

ロボットを制御するためには, 手先の位置や姿勢から各関節 角度を求める逆運動学を解く必要がある。一般に, 自由度が増 すと逆運動学が複雑化するため, 実機でのデバッグ時間が長期 間になる. そこで, 今回はソフトウェアをモジュール化し, 複数 人による並行作業でコーディングを行った。 これらのモジュー ルの妥当性を短期間に確認するために, Fig. 5 のような動作シ ミュレータを構築した。

このシミュレータは，3DCAD で作成したロボットおよび作 業環境のモデルを取り込み, ロボットアームの動作領域や作業 性の確認を行うことができる，また，単腕，双腕，腰，および 双腕協調などの運動学計算を適宜切り替えることができ, 各関 節の現在角度とロボットカメラ画像のリアルタイム表示や, 特 異姿勢の判別を行うことができる. ソフトウェアのデバッグ作 業に当たっては，このシミュレータを活用した。 ハードにより 近い下位のソフトウェアでは, アクチュエータ回りのエラー処 理の対応に, 上位のソフトウェアではアームの生成起動の検証 に用いることで大きなパワーの出る油圧駆動に対し, 安全にデ バッグ作業を行うことができた。

\section{2 油圧流量制御}

2.3 節で述べたと抢り，このロボットはリアルタイムで生成し た指令角度・速度に従って, 各軸の駆動部が動くように制御し 


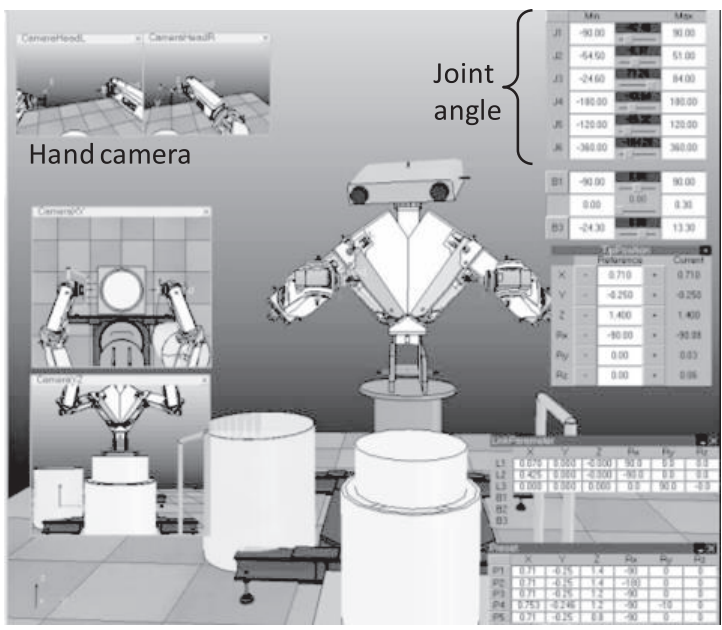

Fig. 5 Outline of simulation

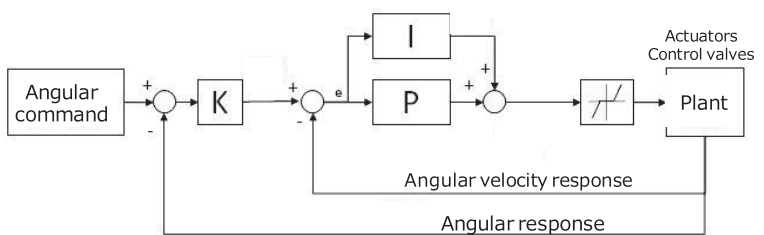

Fig. 6 Block diagram of cascade controller with added velocity control loop

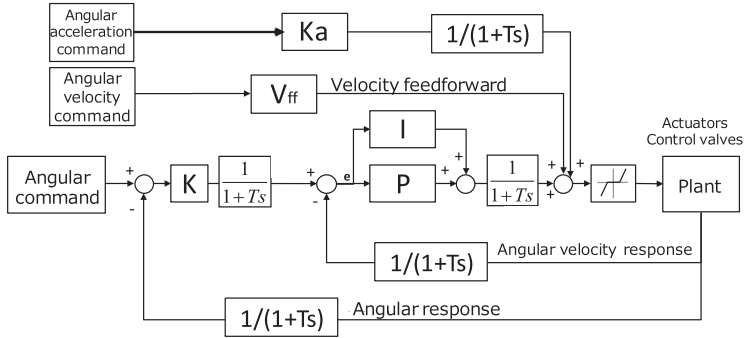

Fig. 7 Block diagram of improved controller with added acceleration feed forward

ている．油圧アクチュエータは油圧バルブによって油圧流量を 制御することで，指令角度・速度に追従させている，ここでは， その制御方法として，二つの方式を検討した。一つは，Fig. 6 に示す速度制御ループをマイナーループに追加したカスケード 制御方式 [8] である。これに, 油圧バルブ固有の特性である不感 帯・ヒステリシスに対応するため, Fig. 6 のように油圧バルブ 入力前に適切なオフセット調節部を設けることで, 微少な流量 変化に対しても，速度応答性を高めることができるようにした．

しかし，この方法では動作開始時と停止時に遅れが発生し， 振動が大きくなる結果となった，そこで，Fig. 7 のように加速 度フィードフォワードとローパスフィルタを組み入れることで, 上記の遅れを改善し速度応答性を高めた。

以上の二つの制御構成にて，速度応答性を比較するため，位 置精度に最も影響を与え，かつ慣性が最も大きい腰部軸を用い て評価した。評価時の外観を Fig. 8 に示し，その結果を Fig. 9 に示す

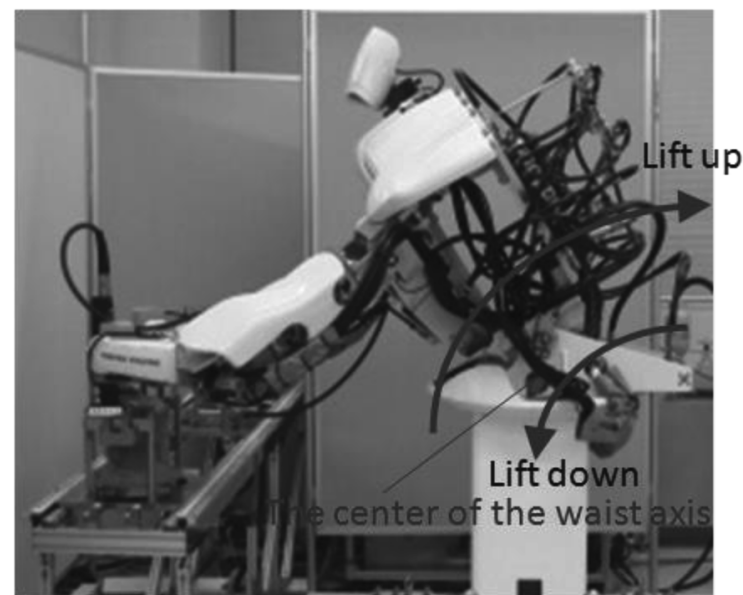

Fig. 8 Experiment external view

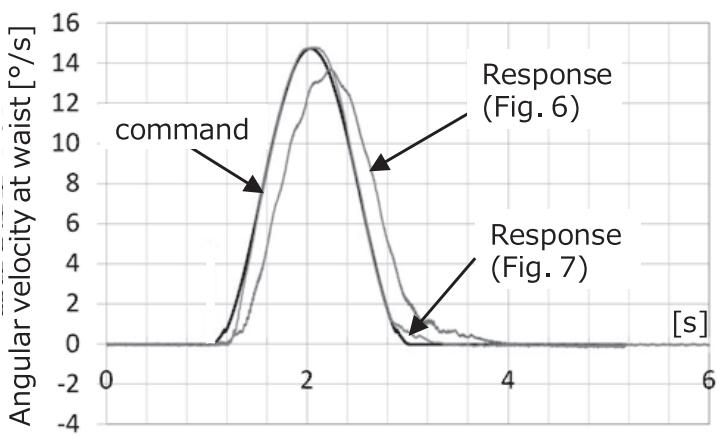

(a) Lift up motion

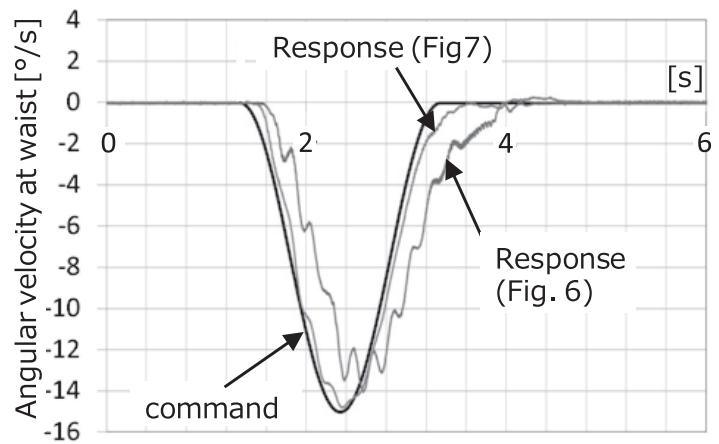

(b) Lift down motion

Fig. 9 Comparison of velocity response of controller with Fig.6 and Fig.7

Fig. 9 の縦軸は速度を示しているが，＋方向が持ち上げ方向 を，一方向が持ち下げ方向を示している.

この結果から，反重力方向である起こし動作開始時に $0.15[\mathrm{~s}]$ 程度の遅れが大幅改善でき，停止時の遅れが $1.1[\mathrm{~s}]$ から $0.4[\mathrm{~s}]$ まで低減できることを確認した。これらは加速度フィードフォ ワードによる効果である。 また，動作中の速度は速度フィード フォワードにより，追従性能を向上できた。これらは，重力方 向である倒れ動作時も同様な効果が得られている.

加えて，倒れ動作時は重力による影響で，応答波形が振動し やすい，そのため，位置・速度フィードバックと指令電圧部に ローパスフィルタを入れることで，振動を抑制している．油圧 


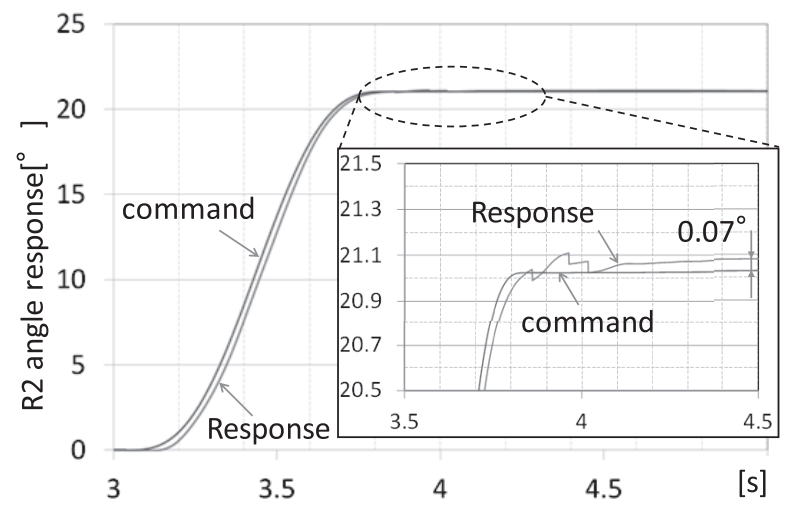

Fig. 10 Joint angle using a hydraulic actuator response

Table 3 Result of the end-effector position estimation

\begin{tabular}{|l|l|l|l|l|l|r|r|}
\hline \multicolumn{5}{|c|}{ Joint angle $^{\circ}{ }^{\circ}$ ] } & \multicolumn{2}{|c|}{ End effector position[mm] } \\
\hline R1 & R2 & R3 & R4 & R5 & R6 & X & Y \\
\hline-14.00 & 22.00 & 68.00 & -114.00 & -103.00 & -121.00 & 1088.74 & -197.77 \\
\hline-14.07 & 21.93 & 67.93 & -114.07 & -103.07 & -121.07 & 1088.72 & -198.61 \\
\hline \multicolumn{6}{|c|}{ The difference } & 0.02 & 0.84 \\
\hline
\end{tabular}

制御バルブそのものの応答性が低いため, 相対的にフィルタに よる遅延の影響は小さい.

\section{3 手先の位置決め精度}

本節では, 油圧アクチュエータと電動アクチュエータを組み 合わせたハイブリッド構成のメリットについて, 手先の位置決 め精度の観点から述べる。

まず，油圧アクチュエータを用いた関節軸の位置決め精度を 明確にするため，Fig. 7 の制御系を用いた際の関節角応答結果 を Fig. 10 に示す. 評価対象は Fig. 2 に示す R2（右腕 2 軸目） 軸とした. Fig. 10 が示すように R 2 軸の関節軸の位置決め誤差 は $0.07^{\circ}$ である.

そこで, 油圧アクチュエータの各関節軸の位置決め精度が R 2 軸の位置決め精度とほぼ同等と仮定すると, 全軸を油圧アクチュ エータで構成した場合の手先精度はTable 3 に示す結果と推定 される。ここで，推定方法には 3.1 節で示したロボットシミュ レータを用いて算出した。

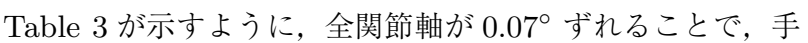
先の位置決め誤差は最大 $0.84[\mathrm{~mm}]$ と推定できる.

次にこのロボットの手先位置決め精度について述べる. 右腕 の油圧・電動両軸を用いて, XY 方向に同時に $50[\mathrm{~mm}]$ 手先を 移動させた場合，各方向の位置決め誤差をプロットしたものを Fig. 11 に示す。この際のロボットの姿勢は, ねじ締め作業を 行う際の代表的な姿勢であり, Table 3 と同一である.

Fig. 11 が示すようにこのロボットの手先精度は $0.3[\mathrm{~mm}]$ 程 度であることから, 全軸油圧アクチュエータで構成した場合と 比べて手先の位置精度は向上している.

\section{4 油圧シリンダ内圧を用いた重量検知機能}

通常のワーク有無検知は, 頭部に搭載されたステレオカメラ を使い，ワーク外観を確認することで，ワーク有無を検知する. しかし，外観確認だけでは，内部部品の取り付け忘れなどを検 出することができない。 そこで，外観上はまったく同じワーク

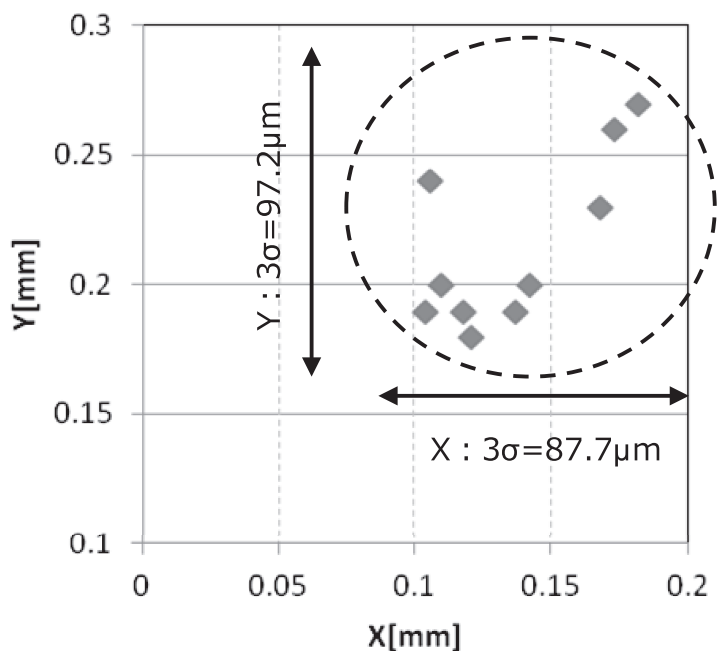

Fig. 11 Position error in work space

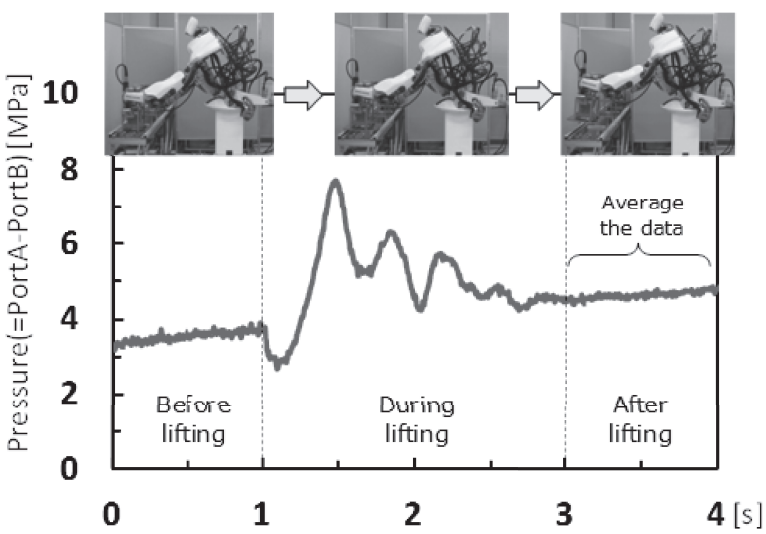

Fig. 12 Pressure response example when lifting parts (weight: $32[\mathrm{~kg}])$

でも不良検出することができるように，ワーク重量を検知する システムを搭載した。

このロボットの腰部は,リンクと油圧シリンダで構成されて おり，人間の腰のように曲げることができる．搭載したワーク 重量検知システムは，この腰部シリンダの 2 箇所の内圧 $(\mathrm{A} / \mathrm{B}$ ポート）を圧力計により以下の手順で測定する.

1）双腕ロボットが，腕を動かしてワークをつかむ.

2）腰軸を一定角度まで回転させ，ワークを持ち上げる.

3）持上げ後 $1[\mathrm{~s}]$ 間停止し，その間の $\mathrm{A} / \mathrm{B}$ ポートの圧力を測 定する. $32[\mathrm{~kg}]$ ワークの持上げ動作による圧力変動の様子を

Fig. 12 に示す.

4） A/B ポートの差圧を平均化し, 重量検知する. Fig. 12 にお ける約 3〜4 [s] の間の部分がこれに該当する.この平均化した 差圧を「圧力值」と呼ぶ.

次に，この圧力值と質量の関係について述べる．質量の異な る 4 種類のワークをそれぞれ 5 回繰返し持ち上げ，その際の圧 力值を測定した. Table 4 にその実験結果を示す.

Fig. 13 は Table 4 の結果をグラフ化したものである. 以上 から, 圧力と総質量の相関係数 $R^{2}=0.93$ と大きく, 相関性が 高いことが分かる。 
Table 4 Relationship between pressure and weight

\begin{tabular}{|c|c|c|c|c|c|}
\hline & Weight[kg] & 12.36 & 13.36 & 15.24 & 17.12 \\
\hline \multirow{4}{*}{$\begin{array}{c}\text { Pressure } \\
{[\mathrm{MPa}]}\end{array}$} & No.1 & 3.089 & 3.172 & 3.271 & 3.549 \\
\cline { 2 - 6 } & No.2 & 3.176 & 3.136 & 3.283 & 3.497 \\
\cline { 2 - 6 } & No.3 & 3.144 & 3.141 & 3.271 & 3.456 \\
\cline { 2 - 6 } & No.4 & 3.142 & 3.139 & 3.245 & 3.478 \\
\cline { 2 - 6 } & No.5 & 3.117 & 3.133 & 3.260 & 3.466 \\
\cline { 2 - 6 } & Average & 3.134 & 3.144 & 3.266 & 3.489 \\
\cline { 2 - 6 } & $3 \sigma$ & 0.097 & 0.047 & 0.044 & 0.110 \\
\hline
\end{tabular}

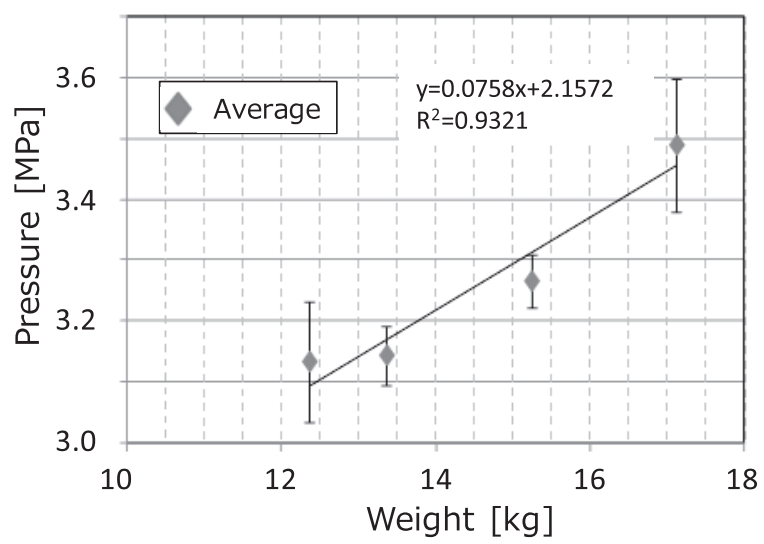

Fig. 13 Relationship between pressure and weight

Table 5 Result of significance test

\begin{tabular}{|c|c|c|}
\hline \multirow{2}{*}{$\begin{array}{c}\text { Weight } \\
\text { difference }\end{array}$} & \multicolumn{2}{|c|}{ Test result } \\
\cline { 2 - 3 } & $\mathrm{P}-$ value & Significant difference (5\%) \\
\hline 1.00 & 0.535 & No \\
\hline 1.88 & 0.000 & Yes \\
\hline
\end{tabular}

また，これらのデータを用いて $\mathrm{t}$ サンプル検定を行った結 果を, Table 5 に示す. この表から, 差分質量が $1.8[\mathrm{~kg}]$ であ れば有意差があることから, 同一姿勢に押いて信頼度 $95 \%$ で約 $2[\mathrm{~kg}]$ の質量差を検知することができる. 一般的にロボットに適 用できるコンパクトな力覚センサやトルクセンサは, 高価, 検 出範囲が小さい, 衝撃に弱いといったことから, 今回開発した ロボットのような可搬質量が大きいロボットには不向きである. また, サイズに関しても油圧センサはトルクセンサと比べて小
さく，柔軟に配置可能という点では機構設計上の大きな利点と なる.

\section{4. ま と め}

今回開発したロボットは, 大きな負荷の掛かる上腕部には油 圧アクチュエータを, 細かな作業を担う前腕部には電動アクチュ エー夕を適切に組み合わせることで, 高可搬質量で器用であり ながら，コンパクトなロボットを実現した．加えて検査機能を 追加することでさらなる自律化を図った。このロボットを生産 工程に展開することで, 従来ハンドクレーン等を用いて人手に よって行われていた重量物（例えば洗濯機や大型コイルなど） の組立・搬送工程を，自動化することが可能になる，さらに生 産現場の共通課題である， $3[\mathrm{~K}]$ （きつい，污い，危険）作業を 排除することができ，作業者の安全確保といった観点からもこ のロボットは貢献できると考えられる.

ロボット産業市場は 1.6 兆円（2015 年）から, 9.7 兆円（2035 年）に増大すると予測されている [9]. 中でも高出力が要求され るサービス分野の介護・福祉（自立支援）および重作業支援分 野においては，4,505 億円（2035 年）の市場に急成長すると見 込まれている，今後はさらなる高出力・軽量化を図り，生産現 場だけでなく急成長するサービス分野への参入を目指して取り 組んでいく.

\section{参 考 文 献}

[1] 一般社団法人日本機械工業連合会: “平成 25 年度ロボット産業・技 術の振興に関する調查研究報告書”, pp.16-55, 2014.

[2] 坂爪裕：セル生産方式の編成原理. 慶應義塾大学出版会, 2012.

[ 3 ] 高橋, ほか：“油圧駆動双腕ロボット”, 東芝レビュー, vol.69, no.5, pp.37-40, 2014.

[4] 高橋, ほか: “油圧駆動双腕ロボット”, 日本ロボット学会第 32 回学 術講演会予稿集 DVD-ROM，3N1-02, p.199, 2014.

[5] 厚生労働省：職場における腰痛予防対策指針及び解説 参考 2 の 別添, http://www.mhlw.go.jp/stf/houdou/2r98520000034et4att/2r98520000034pjn_1.pdf

[ 6 ] 田中, ほか： “油圧・空気圧と電気モー夕の特性比較に関する調査研 究”, 平成 25 年春季フルードパワーシステム講演会論文集, pp.17-25, 2013.

[ 7 ] 加藤, ほか: “セル生産に適したロボットと制御技術”, 東芝レビュー, vol.64, no.1, pp.52-55, 2009.

[8] 松日楽, ほか：ロボットシステム入門. 改訂 2 版. オーム社, 1999.

[9]経済産業省：ロボットの将来市場予測, http://warp.da.ndl.go.jp/ info:ndljp/pid/3487098/www.meti.go.jp/press/20100423003/ 20100423003-2.pdf

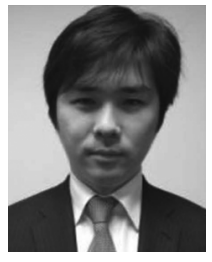

高橋宏昌（Hiromasa Takahashi）

2004 年慶應義塾大学理工学研究科総合システムデ ザイン専攻修士課程修了. 同年（株）東芝入社. 現 在生産技術センターメカトロソリューション推進部 研究主務. メカトロ要素技術および製造設備の開発 に従事. 日本機械学会会員.

（日本ロボット学会正会員）

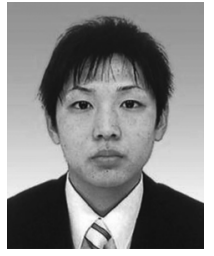

一田伸治（Shinji Ichida）

2009 年愛媛大学工学部機械工学科卒業. 同年 (株) 東芝入社. 現在生産技術センターメカトロソリュー ション推進部研究員. メカトロ要素技術および製造 設備の開発に従事. 


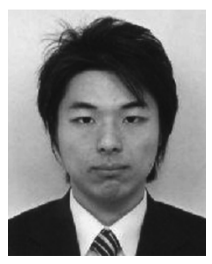

原 直行 (Naoyuki Hara)

2013 年東京都市大学工学研究科機械システム工学 専攻博士課程修了. 同年 (株) 東芝入社. 現在生産 技術センターメカトロソリューション推進部研究員. メカトロ装置の機構や制御技術に興味を持ち，口 ボットの高出力化や操作性向上化技術に関する研究 を行っている. 工学博士 (2013 年). 日本機械学会 会員, IEEE 会員.

(日本ロボット学会正会員)

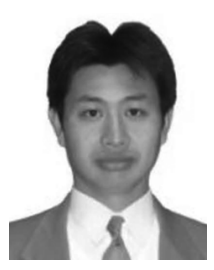

\section{風間拓朗（Takuro Kazama）}

1994 年芝浦工業大学通信工学科. 同年 (株) 芝浦 製作所（現：芝浦メカトロニクス）入社. 2005 年 東芝機械（株）に転籍し，現在同社制御システム事 業部主任. ロボットを応用した装置システムの電気 設計・ソフト開発に従事.

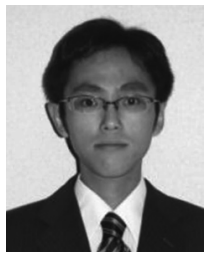

\section{大賀淳一郎 (Junichiro Ooga)}

2004 年大阪大学大学院工学研究科知能機能創成工 学専攻修士課程修了. 同年 (株) 東芝入社. 現在 (株) 東芝 研究開発センター機械・システムラボラ トリー研究主務。アームの運動制御，ロボットのソ フトウェアシステムに関する研究開発に従事. 日本 機械学会会員.

(日本ロボット学会正会員)

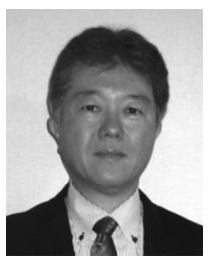

寺井藤雄 (Fujio Terai)

1985 年東京電機大学理工学研究科機械工学専攻修 士課程修了. 同年 (株) 東芝入社. 現在生産技術七 ンターメカトロソリューション推進部研究主幹. メ カトロ装置の機構や制御技術に興味を持ち，ロボッ 卜の高出力化や操作性向上化技術に関する研究を 行っている. 工学博士 (2006 年). 精密工学会会員, 応用物理学会会員，日本技術士会会員。（日本ロボット学会正会員）

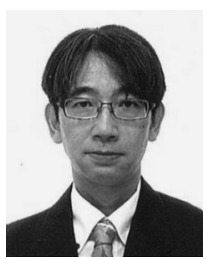

菅野健一郎（Kenichiro Kanno）

1989 年法政大学工学部機械工学科卒業. 同年東芝 FA システムエンジニアリング（株）（現：東芝 IT コントロールシステム）入社. 現在に至る.メカト 口要素技術および製造設備の開発に従事. 